\title{
THE INFLUENCE OF FLEXIBILITY ON THE SPECIFIC MOTOR SKILLS IN BOY-SWIMMERS AGED10-12
}

\author{
Marko Đurović 1 , Tomislav Okičić ${ }^{1}$, Dejan Madić ${ }^{1}$, Milivoj Dopsaj²,
}

Vassilios Thanopoulos ${ }^{3}$, Gina Rozi ${ }^{3}$, Milan Pešić ${ }^{1}$, Milomir Trivun ${ }^{4}$

${ }^{1}$ Faculty of Sport and Physical Education, University of Nis, Serbia

${ }^{2}$ Faculty of Sport and Physical Education, University of Belgrade, Serbia

${ }^{3}$ National and Kapodistrain University of Athens, Department of Aquatics, Athens, Greece ${ }^{4}$ Faculty of Physical Education and Sports, University of East Sarajevo

\begin{abstract}
Summary:
Flexibility is one of the basic motor skills. Flexibility has an impact on the development of swimming skills in young swimmers which can help them achieve maximum results. The aim of this study is to determine the influence offlexibility

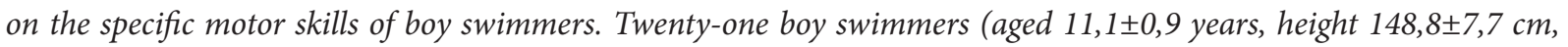
weight 39,4 $\pm 5,6 \mathrm{~kg}$ ) with two years of competitive experience were tested by using three flexibility variables (Sit and Reach, Shoulder flexibility with yardstick and Arm retroflexion), and three specific motor skills variables (Time on $10 \mathrm{~m}$, Time from 10 to $20 \mathrm{~m}$ and Turn time). A regression analysis was used to determine the influence of predictor variables (flexibility skills) on criterion variables (specific motor skills). The results indicated that the system of flexibility variables had a statistically significant influence at the $p=.001$ level, with a multiple correlation coefficient of $.77(R=$ .77), and multiple correlation squared of .59, explaining approximately $59 \%\left(R^{2}=0.59\right)$ of the variance for the criterion variables Turn time. Based on the results, we can conclude that the predictive variable Sit and Reach $(p=.005)$ had a statistically significant influence on the criterion variable Turn time.
\end{abstract}

Key words: swimming, freestyle, time on $10 \mathrm{~m}$, time from 10 to $20 \mathrm{~m}$, turn time.

\section{Introduction}

Swimming belongs to the group of cyclical sports in which based on the form and manner of performance is dominated by relatively simple movements, which are consistently the same and which alternate when swimming a particular technique (Okičić et al., 2007). The sports techniques include the freestyle, backstroke, breast stroke and butterfly (Madić, Okičić, \& Aleksandrović, 2007). The basic aim in sports swimming is rationality which enables an individual to swim a predetermined distance in an economic, steady manner, following straight, using a particular swimming technique (Volčanšek, 1996). The effectiveness of any type of sports activity depends on five basic factors: 1 . the proper performance of movement (sports technique); 2 . energy abilities; 3 . contractile abilities of the muscles; 4 . joint mobility and 5. tactics (Milišić, 2003). According to Malacko (1991), the aim of every sports training is the development of anthropological characteristics on which competitive success depends the most in a certain type of sport or discipline. In the case of swimming, competitive success influences morphological characteristics, motor abilities, functional abilities as well as psy- chological characteristics (Volčanšek, 1996).

Specific motor skills have the greatest connection to sports success, since their structure as well as the intensity of the load is closest to the activities which are performed at competitions. They are acquired and conditioned by the specific nature of the training process of a particular type of sport (Aleksandrović, 2005).

There are a large number of parameters of specific motor skills which can be developed and monitored in swimming, such as: time of the start and turn, absolute duration of the swim, swimming step, tempo of the stroke, swimming only with the hands or only with the legs, etc. (Ahmetović, 1994; Maglischo, 2003). Monitoring the development of specific motor skills is important in the sense of achieving a rational swimming technique. There are many studies in which the authors studied the influence of specific motor skills on swimming results (Jurimae et al., 2007; Latt et al., 2010).

Small children are very flexible, but with time there is a decrease in flexibility. That is why it is impor- 
tant to implement exercises for its increase through all the phases of development of young athletes (Bompa, 2005) and so also among young swimmers. In accordance with the aforementioned, from the beginning when young swimmers start taking part in swimming, exercises which are meant to increase flexibility should be a component part of each of their training sessions. The very training in water (active cyclical work which includes alterations between tonus and relaxation during changes in the phase of the stroke, decreased muscle tonus in the horizontal position) leads to an increase in the flexibility of the joints in the shoulder area, pelvis and ankles (Volčanšek, 1996). The influence of flexibility on the results in swimming among young swimmers has been confirmed by Zenić, Antulov \& Ćavar (2007) and Jorgić, et al. (2010) in their studies.

The aim of this study was to determine the influence of the implemented tests for the evaluation of flexibility on three specifically motor skills in swimming among young boy swimmers.

\section{The method}

In this study the sample of participants consisted of 21 swimmers of an average age of $11 \pm 6$, who have been training in the swimming club "Nis2005" for at least two years. The average height and weight of the swimmers who participated in this study was $147.2 \pm 8.4 \mathrm{~cm}$ and $39.2 \pm 5.8 \mathrm{~kg}$.

To evaluate flexibility, three tests were used (Okičić, 2007):

- Sit and Reach (This test is used to evaluate the flexibility the lower back and hamstring muscles. The participant sits on the floor with his legs stretched out straight ahead. The feet are placed flat against the sit and reach box (Picture 1.). Both knees should be stretched and pressed flat on the floor. The participant has the goal to reach forward along the measuring line as far as possible. To avoid negative values we rely on Okičić (1999) who suggests there be a distance $20 \mathrm{~cm}$ at the level of the feet. Repeat two times, and the best attempt is used for analysis),

- Shoulder flexibility with yardstick (This is a shoulder rotation flexibility test. The participant holds a yardstick in front of the body, hands wide apart and palms facing downwards. He lifts the yardstick over his head behind his back, maintaining a hand grip on the object (Picture 2.). He repeats the test protocol, moving the hands closer together each time until the attempt cannot be completed. Repeat two times, and the best attempt is used for analysis),

- Arm retroflexion (This test is used to evaluate the flexibility of the muscles of the shoulder belt. The participant stands with his arms straight forward. The invigilator positions a stationary part of the goniometer along the torso so that it follows the middle line of the body while the mobile part follows the movement of the hands of the participant (Picture 3.). The participant has the task to perform as many hand movements backwards as possible in an outstretched position, and without moving the remaining parts of the body. Repeat two times, the best attempt is used for analysis).
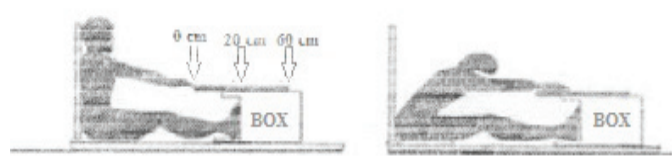

Figure 1. Sit and Reach test

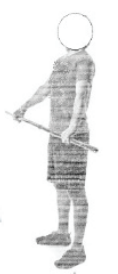

Shoulder flexibility with yardstick test

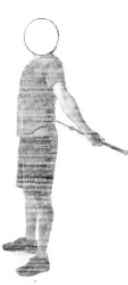

Figure 3 Arm retroflexion test 
And three tests for the evaluation of specific motor abilities (Okičić, 2007):

- Time to $10 \mathbf{m}$ (time elapsed from the starting signal until the swimmer's head reaches the $10 \mathrm{~m}$ mark, respectively),

- Time from 10 to $20 \mathrm{~m}$ (time elapsed from the $10 \mathrm{~m}$ until the swimmer's head reaches the $20 \mathrm{~m}$ mark, respectively),

- Turn time (the time needed for the swimmer to swim a distance of five meters prior to performing a turn and a distance of up to five meters after performing a turn).

At distances of 10 and 20 meters from the starting block along the vertical edge of the pool, markers are placed in the form a line of a different color than the color of the edge of the pool. Two invigilators with stopwatches stand by the pool, one at the marker at a distance of 10 meters from the start, and the other at the marker at a distance of 20 meters from the start, hands outstretched above the pool (Picture 4.). When the starter gives the mark, they turn on their stopwatches, and stop them as soon as the head of the swimmers pass an imaginary line at the level of the mark. The swimmers swam $30 \mathrm{~m}$ ( 25 $m+5 m$ ), the test was repeated twice, and the better attempt at the overall swim at a distance of $30 \mathrm{~m}$ was taken for further analysis (Okičić, 1999).

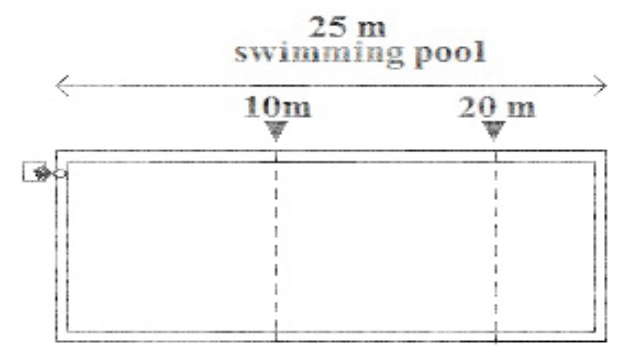

Figure 1. Specific Motor Skills tests

In order to determine the influence of the overall predictor system of variables on the criterion variables, a regression analysis was used, where the following statistical parameters were calculated: the multiple correlation coefficient (R), the coefficient of determination $\left(\mathrm{R}^{2}\right)$, the result of the F-test (F) and level of statistical significance (p). In order to determine the influence of each individual variable in the regression analysis, the following was calculated: the coefficient of the partial correlation (part-r), the correlation coefficient (r), standardized coefficients of a partial regression (Beta), the results of the $t$-test $(t)$ and statistical significance (p). For the statistical significance, we used a level of significance of $0.05(\mathrm{p} \leq 0.05)($ Bala, 1990).

\section{Results and discussion}

Table 1. Descriptive statistics

\begin{tabular}{|l|l|l|l|l|l|}
\hline Variables & $\mathrm{N}$ & Mean & Std. Dev & Min & Max \\
\hline Sit and Reach (cm) & 21 & 23.00 & 5.76 & 13.00 & 35.00 \\
\hline $\begin{array}{l}\text { Shoulder flexibility with } \\
\text { yardstick (cm) }\end{array}$ & 21 & 44.32 & 16.65 & .00 & 70.00 \\
\hline Arm retroflexion (degrees) & 21 & 18.14 & 14.25 & 2.00 & 62.00 \\
\hline Time to 10 m (s) & 21 & 5.95 & .79 & 4.34 & 7.35 \\
\hline Time from 10 to $20 \mathrm{~m}(\mathrm{~s})$ & 21 & 8.04 & .95 & 6.76 & 10.91 \\
\hline Turn time (s) & 21 & 4.99 & .82 & 3.55 & 6.59 \\
\hline
\end{tabular}

Legend: N - number of participants, Mean - mean, Std.

Dev - standard deviation, Min - minimal result, Max maximal result

Table 2. Regression analysis of Flexibility and Time to $10 \mathrm{~m}$

\begin{tabular}{|l|l|l|l|l|l|}
\hline \multicolumn{5}{|c|}{$\mathrm{R}=0.54, \mathrm{R}^{2}=0.29, \mathrm{~F}=2.3, \mathrm{p}=0.111$} \\
\hline & Beta & $\mathrm{r}$ & Part-r & $\mathrm{t}$ & $\mathrm{p}$-level \\
\hline $\begin{array}{l}\text { Shoulder flexibility with } \\
\text { yardstick }\end{array}$ & .235 & 0.35 & 0.20 & .821 & .423 \\
\hline Sit and Reach & -.437 & -0.50 & -0.40 & -1.788 & .092 \\
\hline Arm retroflexion & .023 & -0.38 & 0.02 & .072 & .944 \\
\hline
\end{tabular}

Table 3. Regression analysis of Flexibility and Time from 10 to $20 \mathrm{~m}$

\begin{tabular}{|l|l|l|l|l|l|}
\hline \multicolumn{5}{|c|}{$\mathrm{R}=0.56, \mathrm{R}^{2}=0.32, \mathrm{~F}=2.6, \mathrm{p}=0.085$} \\
\hline & Beta & $\mathbf{r}$ & Part-r & $\mathrm{t}$ & $\mathrm{p}$-level \\
\hline $\begin{array}{l}\text { Shoulder flexibility with } \\
\text { yardstick }\end{array}$ & .271 & 0.46 & 0.23 & .966 & .348 \\
\hline Sit and Reach & -.274 & -0.44 & -0.27 & -1.141 & .270 \\
\hline Arm retroflexion & -.148 & -0.49 & -0.11 & -.467 & .647 \\
\hline
\end{tabular}

Table 4. Regression analysis of Flexibility and Turn time

\begin{tabular}{|l|l|l|l|l|l|}
\hline \multicolumn{6}{|c|}{$\mathrm{R}=0.77, \mathrm{R}^{2}=0.59, \mathrm{~F}=8.1, \mathrm{p}=0.001$} \\
\hline & Beta & $\mathrm{r}$ & Part-r & $\mathrm{t}$ & $\mathrm{p}$-level \\
\hline $\begin{array}{l}\text { Shoulder flexibility with } \\
\text { yardstick }\end{array}$ & -.117 & -0.42 & -0.13 & -.538 & .597 \\
\hline Sit and Reach & -.599 & 0.73 & 0.61 & 3.211 & .005 \\
\hline Arm retroflexion & .175 & 0.58 & 0.17 & .709 & .488 \\
\hline
\end{tabular}

Table 1. shows the values of basic parameters of descriptive statistics for all the studied variables. The results of the regression analysis in Table 2. and 3. indicate that the entire system of predictor variables for the evaluation of flexibility does not have a statistically significant influence on Time for $10 \mathrm{~m}$ $(\mathrm{p}=0.111)$ and Time from 10 to $20 \mathrm{~m}(\mathrm{p}=0.085)$ for the tested group of swimmers. Thus, there is no statistically significant influence of any of the individ- 
ually studied variables. However, it might be said that the $\mathrm{p}$ value $(p=0.085)$ is on the borderline level of statistical significance and it can be concluded that the entire system of predictor variables has an influence on the evaluation of flexibility for Time from 10 to $20 \mathrm{~m}$ even though it is not statistically significant. The results of the regression analysis in Table 4. indicate that the entire system of predictor variables used to evaluate flexibility have a statistically significant influence on Turn time for the tested groups of swimmers $(\boldsymbol{p}=\mathbf{0 . 0 0 1})$, where the multiple correlation coefficient $(\mathrm{R})$ has a value of 0.8 . The coefficient of determination $\left(\mathrm{R}^{2}\right)$ has a value of 0.59 , which means that the shared variability is explained only by $59 \%$. Studied individually, the statistically significant influence on turn time was determined for the variable Sit and Reach at the level of significance $(\mathrm{p}=0.05)$. The negative sign, or positive influence of the variable of deep hyperextensions on turn time indicates that in this study the swimmers with a higher value of flexibility in the hip joint have a shorter turn time, that is, that they are able to perform the flip turn more quickly. The Sit and Reach test is valid for the evaluation of flexibility of the lower back and hamstring muscles (Hui \& Yuen, 2000). The results of the realized research have confirmed the existing claims that flexibility has a significant influence on the swimming results (Okičić et al., 1996; Zenić et al., 2007; Jorgić et al., 2010). Leko (2001) in his extensive study in which he relied on a great number of anthropometric characteristics and motor skills, a factor analysis, determined that in addition to the dynamometric force, endurance and explosive strength, flexibility as well represents the most important factor of success in swimming for the 50, 100, 200 and 400 freestyle. In addition, Okičić, 1996 concluded that among younger swimmers flexibility of the shoulders, knee and hips has a great influence on swimming results and that it is possible to perform swimmer selection based on the parameter of flexibility. Okičić (2007) determined that flexibility has a relevant influence on swimming technique and other swimming motor skills. Also, flexibility of the hips has a relevant influence on the assessment of the quality swimming techniques (Rađo \& Pivač, 1996).

\section{Conclusion}

The results obtained by means of a multivariate and univariate regression analysis suggest that boy swimmers who possess a high extent of flexibility of the hip joint perform the flip turn with much greater efficiency than swimmers with decreased hip joint flexibility. It was also determined that the entire system of flexibility variables (Sit and Reach, Shoulder flexibility with yardstick and Arm retroflexion) at the multivariate level has a statistically significant influence on Turn time. We can conclude that younger age boy swimmers, in addition to regular swimming training sessions, should implement flexibility training on dry land so as to achieve the best results possible in swimming.

\section{References}

Ahmetović Z. (1994). O treningu plivača. Novi Sad: Zavod za fizičku kulturu Vojvodine.

Aleksandrović M. (2005). Struktura i relacije antropološkog statusa vaterpolista i učenika uzrasta 12 godina. Neobjavljena doktorska disertacija. Skoplje: Fakultetu za fizičku kulturu. Bompa, T. (2005). Cjelokupni trening za mlade pobjednike. Zagreb: Gandalf

Hui, S. S., \& Yuen, P. Y. (2000). Validity of the modified back-saver sit-and-reach test: a comparison with other protocols. Medicine and Science in Sports and Exercise, 32(9), pp. 1655-1659. https://doi. org/10.1097/00005768-200009000-00021

Jorgić B., Okičić T., Aleksandrović M. \& Madić D. (2010) Influence of Basic and Specific Motor Abilities on Swimming Results. Acta Kinesilogica, 4(2), pp. 73-77.

Jurimae J., Halljaste K., Cicchela, A., Latt E., Purge P., Leppik A. \& Jurimae T. (2007). Analysis of swimming performance from physical, physiological, and biomechanical parameters in young swimmers. Pediatric Exercise Science, (19), pp. 70-81.

Latt E., Jurimae J., Maestu J., Purge P., Ramson R., Haljaste K., Keskinen K.L., Rodriguez F. A. \& Jurimae T. (2010). Physiological, biomechanical and anthropometrical predictors of sprint swimming performance in adolescent swimmers. Journal of Sports Science and Medicine, 9 (3), pp. 398-404.

Madić D., Okičić T., Aleksandrović M. (2007). Plivanje. Niš: SIA.

Maglischo E.W. (2003). Swimming fastest. Champaign: Human Kinetics.

Malacko J. \& Popović D. (2001). Metodologija kineziološko antropoloških istraživanja. Leposavić: Fakultet za fizičku kulturu.

Milišić, B., (2003). Upravljanje treningom. Beograd: SIA. Okičić T. (1999). Uticaj treninga plivanja na brzinu kao i na promene nekih dimenzija antropoloških karakteristika plivača mlađih kategorija. Neobjavljeni Magistarski $\mathrm{rad}$, Niš: FSFV.

Okičić T., Ahmetović Z., Madić D., Dopsaj M., Aleksandrović M. (2007). Plivanje - praktikum. Niš: SIA.

Okičić, T. (1996). Uticaj fleksibilnosti na rezultate u plivanju [Influence of flexibility on swimming results]. U N. Živanović (Ur.), Zbornik radova VI nacionalnog naučnog skupa sa međunarodnim učešćem „FIS komu- 
nikacije 1995“, (pp. 202-204). Niš: Filozofski fakultet Serija Fizička kultura.

Rađo, I., \& Pivač, M. (1996). Uticaj bazično-motoričkih sposobnosti na uspešnost u savladavanju sportskih tehnika plivanja [Influence of basic-motor skills on success in sport-swimm techniques achievment]. N. Živanović (Ur.), Zbornik VI nacionalnog naučnog skupa sa međunarodnim učešćem „FIS komunikacije 1995“. (155-158). Niš: Filozofski fakultet - Serija Fizička kultura.
Volčanšek B. (1996). Sportsko plivanje: plivačke tehnike $i$ antropološka analiza. Zagreb: Fakultet za fizičku kulturu sveučilišta u Zagrebu.

Zenić N., Antulov J., \& Ćavar M. (2007). Biološka dob kao temeljna antropološka pretpostavka treninga $u$ sportskom plivanju. U: V. Findak (Ur.), Zbornik radova 16. Letnja škola kineziologa Republike Hrvatske (str. 270-273). Poreč: Hrvatski kineziološki savez. 